\title{
An overview of mycotoxins, their pathogenic effects, foods where they are found and their diagnostic biomarkers
}

\author{
João Victor Batista da SILVA ${ }^{1}$, Carlos Augusto Fernandes de OLIVEIRA², Leandra Náira Zambelli RAMALHO ${ }^{1 *}$
}

\begin{abstract}
Mycotoxins are products of the secondary metabolism of fungi, which can be present in food as contaminants. According to Food and Agriculture Organization (FAO), these substances, making them relevant to global health, contaminate approximately $25 \%$ of all food worldwide. The occurrence of exposure to these mycotoxins is more common in developing countries, where their effects are more harmful to health due to the high rate of malnutrition in these places. The damage caused by them can manifest acutely or chronically, and among them stand out hepatotoxicity, nephrotoxicity, immunogenicity, carcinogenesis, mutagenesis, and teratogenesis and are associated with particularly dangerous nutritional disorders in children from poorer regions. This review focuses on aflatoxins, fumonisins, zearalenone, deoxynivalenol and ochratoxins, with special attention to their impacts on human and animal health, based on experimental studies and case reports. The biomarkers most used in the detection of these substances based on their metabolism are also discussed.
\end{abstract}

Keywords: mycotoxin biomarkers; fungi; toxicity; carcinogenesis.

Practical Application: Control of food contamination by mycotoxins.

\section{Introduction}

Mycotoxins are secondary products of fungal metabolism, with a high capacity to cause damage to human and animal health (Bennett \& Klich, 2003).

Fungi can naturally proliferate in food and are very commonly found in grains used for animal and human food. The growth is mainly favored by humidity and temperature. Inadequate harvesting and storage practices contribute to fungal contamination (Batatinha et al., 2008).

The presence of fungi in food does not necessarily indicate that they are contaminated with mycotoxins; similarly, the elimination of the fungi does not guarantee that the mycotoxin has been removed because they have high stability (Turner et al., 2009).

In Brazil, mycotoxins can be found in isolation or in combination in foods such as peanuts, grains, cereals, corn, wheat and animal foods such as milk, eggs and meat. The fact that these mycotoxins can be found in various foods makes them of great importance in public health, in addition to causing negative impacts on the economy (Maziero \& Bersot, 2010; Calori-Domingues et al., 2016).

There are several mycotoxins produced by different types of fungi. Sometimes a single fungus species can produce different mycotoxins, making the discussion about the toxic potential of association between them relevant (Sweeney \& Dobson, 1998; Marin et al., 2013).

The ingestion of food contaminated by mycotoxins can cause damage to human and animal health and can lead to death, depending on the mycotoxin and the amount ingested (Peraica et al., 1999). Among the harmful effects caused by mycotoxins, hepatotoxicity, nephrotoxicity, carcinogenesis, immunosuppression, and mutagenicity stand out (Rocha et al., 2014). In addition, some mycotoxins, such as aflatoxins and fumonisins, have teratogenic potential and may cause bone malformation and poor development in fetal organs, as demonstrated in previous studies with experimental models (Fetaih et al., 2014; Abdel-Wahhab et al., 2004).

There are several methods that aim to detect mycotoxins in food samples and biological samples. Among the techniques stand out are immunoenzymatic assays and chromatography that can isolate molecules (Chauhan et al., 2016; Pimpitak et al., 2020). Chromatography becomes more effective when associated with mass spectrometry, as it allows a greater amount of information about the analyte to be obtained, making its identification more assertive (Chiaradia et al., 2008; Medina et al., 2019). Fluorescence methods can also be used to detect food contamination, mainly by aflatoxins (Raota \& Giovanela, 2016). Currently, the most commonly used techniques for determining mycotoxin exposure are high-performance liquid chromatography with fluorescence detection (HPLC-FLUO) and high-performance liquid chromatography coupled with sequential mass spectrometry (LC-MS/MS) (Al-Jaal et al., 2019).

Residues and metabolites of mycotoxins, such as aflatoxin, can be identified in humans and animal viscera and excreta, and these are important markers of poisoning by these substances (Ramalho et al., 2018; Jager et al., 2016).

${ }^{1}$ Departamento de Patologia e Medicina Legal, Faculdade de Medicina de Ribeirão Preto, Universidade de São Paulo - USP, Ribeirão Preto, SP, Brasil

${ }^{2}$ Departamento de Engenharia de Alimentos, Faculdade de Zootecnia e Engenharia de Alimentos, Universidade de São Paulo - USP, Pirassununga, SP, Brasil

${ }^{*}$ Corresponding author: 1ramalho@fmrp.usp.br 
An important point in the study of poisoning by mycotoxins is that food contamination is intended for the consumption of farm animals, culminating in animal products contaminated with metabolites of these substances, which contributes to human exposure to mycotoxins (Dias, 2018).

Chronic exposure to small amounts of mycotoxins in food is a major global health problem due to the ability of these substances to lead to the development of various pathologies, which makes monitoring mycotoxins in foods important for generating new technologies. Detection and elimination of these substances aim at reduction of exposure and therefore of the diseases caused by them (Smith et al., 1995; Maziero \& Bersot, 2010).

Studies indicate that the presence of mycotoxins in food is more common in developing countries, and the population of these countries will often be exposed to food contaminated with one or more mycotoxins (Bryden, 2007).

It is estimated that approximately $25 \%$ of the entire world's food is contaminated by mycotoxins (Bennett \& Klich, 2003). Due to the importance of mycotoxins for public health, legislation defines the maximum permitted amount of these substances in food. In Brazil, these quantities are stipulated in RDC No. $7 / 2010$ of the national health surveillance agency (ANVISA).

The purpose of this review is to discuss the following mycotoxins: aflatoxins, fumonisins, zearalenone, deoxynivalenol and ochratoxins, raising the main topics about their impact on human and animal health and the biomarkers used to evidence exposure to these substances.

\section{Mycotoxins}

\subsection{Aflatoxins}

Aflatoxins are mycotoxins of common occurrence in Brazil and are produced by fungi of the genus Aspergillus spp., mainly A. flavus, A. parasiticus and A. nomius (Caldas et al., 2002). The group of aflatoxins has many representatives among fungal metabolism products and metabolic products of these substances in the body. The toxins B1, B2, G1 and G2 stand out due to their toxicological importance, and aflatoxin B1 is the most important due to its carcinogenic potential. Aflatoxin B1 is classified by the International Agency for Research on Cancer (IARC) as a group 1 carcinogen, which means that aflatoxin B1 (AFB1) is part of the group of substances with the greatest carcinogenic potential (International Agency for Research on Cancer, 2002).

The products of hepatic metabolism of aflatoxins are responsible for their toxic effects (Batatinha et al., 2008). These metabolites cause acute liver damage when ingested in large quantities or express a high potential carcinogenic when ingested continuously, causing damage in DNA through adduct formation and interfering with protein metabolism (Wild \& Turner, 2002).

The ingestion of aflatoxins is especially relevant in developing countries, where contact with these substances occurs, from the development embryo, into adulthood (Gong et al., 2002). One of its effects would be the impairment in the development of children, in addition to the association with nutritional disorders such as Kwashiorkor (McMillan et al., 2018).
Poor diets, from the nutritional point of view, seem to be related to the increase in the toxic and carcinogenic effects of aflatoxins, a fact that may be related to the low intake of substances with antioxidant potential such as vitamins, a common condition in the poorest populations of countries under development (Rogers \& Newberne, 1971).

In some countries, mainly in Africa and Asia, children become fed almost exclusively with potentially contaminated grain, and after being weaned, this is due to the economic condition. It was shown that the increase in serum concentration of aflatoxin in these children is also related to dwarfism (Alamu et al., 2020).

Experimental studies in rats demonstrate that exposure to AFB1 during the period of embryonic development can lead to genotoxic changes, favoring the development of neoplasms in adulthood (Chawanthayatham et al., 2015). In addition, the mutagenic effect of aflatoxins during embryonic development can lead to a series of morphological and behavioral changes, which may lead to reproductive disability and even death (Fetaih et al., 2014; Supriya \& Reddy, 2015).

When high doses of aflatoxin are ingested, they usually cause acute poisoning; although acute poisoning outbreaks are not so common, they usually go with anorexia, general malaise, low fever, and may progress with emesis, severe abdominal pain, acute hepatitis and death (Azziz-Baumgartner et al., 2005).

The biomarkers used to determine exposure to aflatoxins are metabolites of AFB1, such as aflatoxin M1 (AFM1), aflatoxin P1 (AFP1), aflatoxin Q1 (AFQ1), aflatoxin-albumin, AFB-N7 guanine and aflatoxicol (AFL), present in biological fluids (Bando et al., 2007). AFB1 and metabolites can be detected in the blood, urine and feces of humans and animals, which is an important tool for assessing the exposure of individuals to aflatoxins (Fernandez et al., 1997; Mykkänen et al., 2005). For the monitoring of these biomarkers, analytical techniques that are sensitive, specific and that can be applied to many samples are necessary (Groopman \& Kensler, 1999).

Free AFB1 can be found in the blood, but its levels are high for a short time after intake, making it not a good exposure marker, as aflatoxin-albumin is found in blood samples for up to 20 days after exposure (Jager et al., 2016).

AFM1 can be found in urine, feces and milk, and in the case of lactating women and animals, with high toxic potential, this metabolite is especially important in the contamination of children during breastfeeding and in commercial milk from animals (Diaz \& Sánchez, 2015; Giovati et al., 2015; Hajmohammadi et al., 2019; Ahmadi, 2020). AFM1 is further classified by IARC as agent 2B for its carcinogenic potential in humans (International Agency for Research on Cancer, 1993). The assessment of AFM1 levels in urine can also be used as a biomarker to determine the effectiveness of methods that aim to decrease exposure to AFB1 (Mitchell et al., 2013).

Another important biomarker is AFB-N7-guanine, a lead product of AFB1 epoxide with a guanine of the DNA molecule that is excreted in urine. AFB-N7-guanine is a biomarker that shows, in addition to exposure to AFB1, DNA damage, the 
main factor in the development of hepatocellular carcinoma (Dohnal et al., 2014).

The search for AFB1 biomarkers in hair and nail samples is relevant, as it may indicate exposure that has occurred for a longer time (Mupunga et al., 2017).

\subsection{Fumonisins}

Fumonisins are a group of mycotoxins produced mainly by fungi of the genus Fusarium spp.. These mycotoxins are found in foods such as corn and forages and are associated with liver damage and some types of neoplasms. The variant of greater importance is fumonisin B1 (FB1), classified by IARC as a 2B group member with carcinogenic potential for humans (International Agency for Research on Cancer, 1993). The mechanism of action of FB1 consists of the interruption of sphingolipid synthesis by inhibiting sphingosine- $\mathrm{N}$-acetyltransferase, inducing oxidative stress, altering DNA methylation, and modulating autophagy and stress of the endoplasmic reticulum (Voss \& Riley, 2013; Liu et al., 2019).

Among the diseases caused by fumonisins in animals are leukoencephalomalacia of the horse and pulmonary edema in swine (Marasas et al., 1988; Harrison et al., 1990). In addition, FB1 has been shown to cause hepatotoxicity and nephrotoxicity in rats (Voss \& Riley, 2013). In humans, fumonisins are constantly found in places with a high incidence of esophageal cancer, which is therefore a sign that these toxins may play a role in the development of this neoplasm (Come et al., 2019).

In underdeveloped countries where maize and derivative feeding rates are high, the fumonisins present in these foods seem to be related to impaired child development (Chen et al., 2018).

The experimental administration of FB1 is related to malformations in the closing of the neural tube in mice (Gelineauvan Waes et al., 2009). Skeletal anomalies are also observed in rats, as well as failure to develop the organs and even decrease the number of pups per litter (Abdel-Wahhab et al., 2004).

In rats, liver damage caused by FB1 can lead to an imbalance in the mineral composition of bones, leading to decreased bone strength (Rudyk et al., 2019).

The toxic action of fumonisins occurs mainly by inhibiting the function of the enzyme ceramide synthase, leading to a decrease in the production of sphingolipids and, therefore, accumulation of sphinganine (Sa) and sphingosine (So). Sphingosine and sphinganine in serum, tissues, urine, and feces can be used as biomarkers of exposure to fumonisins (Van der Westhuizen et al., 1999).

In rats, the rates of Sa, So and free FB1 in the urine remain high for a longer time when compared to serum, so the urinary determination of $\mathrm{Sa} / \mathrm{So}$ is more effective for determining exposure to fumonisins (Cai et al., 2007).

High amounts of free FB1 have been found in the urine of people who have eaten contaminated corn in China, indicating free urinary FB1 as a potential biomarker of human exposure to fumonisins (Xu et al., 2010). The Sa/So ratio can be used to determine the degree of exposure to fumonisins; in addition, men have a greater amount of Sa and So in the urine when exposed to FB1 (Qiu \& Liu, 2001).

Fumonisins can still be identified in human and animal hair, which is an important tool in detecting exposure to these mycotoxins in populations, and the toxicokinetic mechanism that explains the presence of fumonisins in the hair has yet to be elucidated (Sewram et al., 2003; Souto et al., 2017).

\subsection{Zearalenone}

Zearalenone (ZEN) is a nonsteroidal estrogenic mycotoxin produced mainly by fungi of the genus Fusarium spp. ZEN can be produced in colder climates and can be found in various foods, mainly in corn. This mycotoxin acts in the body as an estrogenic substance, and its mechanism consists of binding to receptors for $17 \beta$ estradiol, leading to hyperestrogenism and reproductive disorders (Batatinha et al., 2008).

The metabolites of ZEN, $\alpha$ and $\beta$-zearalenol have higher affinity for estradiol receptors and are therefore primarily responsible for the mechanism of action (Fitzpatrick et al., 1989).

The ingestion of food contaminated with ZEN leads to endocrine disorders due to its similarity to naturally produced estrogenic hormones, and constant hormonal stimulation can lead to the development of hormone-dependent neoplasms (Kowalska et al., 2016).

In Tunisia, significant amounts of ZEN and metabolites in the urine of patients with breast cancer have been identified, indicating a possible role of this mycotoxin in the development of this neoplasm (Belhassen et al., 2015). The association between ZEN and carcinogenesis is the subject of discussion, considering that experimental studies demonstrate the ability of this substance to decrease the possibility of the development of malignant neoplasms in rats in the prepuberty period (HilakiviClarke et al., 1999). Other experimental studies also evaluated whether ZEN is related to the progression of breast cancer through inhibition of apoptosis mechanisms and promotion of cell proliferation mechanisms (Yu et al., 2005).

Experimental studies also demonstrate that exposure to ZEN can lead to the death of Sertoli cells in mice by inducing reactive oxygen species and the ATP/AMPK pathway (Zheng et al., 2018). Other mechanisms that induce apoptosis by ZEN are due to the stress of the endoplasmic reticulum and the activation of autophagy, as demonstrated with immortalized Leydig cells from goats (Yang et al., 2017).

In humans, consumption of food contaminated with ZEN during pregnancy can expose the fetus to this mycotoxin and its metabolites (Warth et al., 2019). Experimental studies in rats indicate that gestational exposure to ZEN blocks the fetal development of Leydig cells, which is an important indicator that this exposure leads to anomalies in the development of the male reproductive tract (Pan et al., 2020).

Estimates of exposure to ZEN in humans have shown that a large part of the population consumes safe amounts of this mycotoxin; however, in different parts of the world, exposure has not been reported and may present different results in populations exposed to potentially contaminated food (Maragos, 2010). 
The biomarkers used for the detection of zearalenone are ZEN free and its metabolites $\alpha$ and $\beta$ zearalenol ( $\alpha$-ZEL and $\beta$-ZEL) and $\alpha$ and $\beta$ zearalanol ( $\alpha-Z A L$ and $\beta-Z A L)$, in addition to the conjugates with glucuronic acid as $\beta$-zearalenol-14-glucuronide (Frizzell et al., 2015).

In humans, urine samples are the main way to assess exposure to ZEN, with $a-Z O L$ found in greater quantities, followed by ZEN and finally $\beta$-ZOL (Ali \& Degen, 2018).

\subsection{Deoxynivalenol}

Deoxynivalenol (DON) is a mycotoxin produced by fungi of the genus Fusarium spp. that can be found in several grains and products of animal origin. The main damage to human and animal health occurs mainly in an acute form leading to nausea, emesis, diarrhea, abdominal and head pain, dizziness, and fever, which can evolve to death depending on the amount ingested. The chronic effects are mainly on the immune, reproductive, and gastrointestinal systems. This toxin acts mainly on the neuroendocrine system, inhibiting the growth hormone cascade and stimulating inflammatory responses. In addition, it acts on the gastrointestinal tract, inhibiting gastric emptying and causing imbalance in the intestinal mucosa, consequently affecting the absorption of nutrients. (Fioramonti et al., 1993; Pestka, 2010; Sobrova et al., 2010).

Ingestion of DON, in addition to its acute effects, can lead to genotoxicity on human lymphocytes, probably resulting from the decrease in antioxidant substances, leading to DNA damage by oxidative stress (Yang et al., 2014). Furthermore, DON seems to have a genotoxic effect on E. coli strains present in the human intestine, which is a possible indicator of its participation in intestinal carcinogenesis, although previous studies have ruled out that DON may play some role in the development of neoplasms (Pestka, 2010; Payros et al., 2017). DON seems to cause emetic effects in humans, and when its effects are evaluated in animals, it is possible to observe effects on the immune system, anorexia and loss of nutritional efficiency as well as adversely affect reproductive capacity (Pestka \& Smolinski, 2005).

Reviews carried out in cell lines of human intestinal mucosa suggest that DON acts by modulating the activity of intestinal transporters, thus acting on nutrient absorption, and the main mechanism of injury occurs by the inhibition of protein synthesis and the decrease in intercellular junction constituents (claudina-4). (Maresca et al., 2002; Van de Walle et al., 2010).

The toxicity of $d$ to DON varies according to the species affected, as well as other mycotoxins, and pigs are more sensitive and ruminants are the most resistant (Pestka, 2007).

Experimental studies demonstrate that DON may have teratogenic potential related to disorders of bone and cartilage development; however, such findings are open to discussion, considering that other studies do not show changes in embryonic development, which is a point to be clarified in the future (Khera et al., 1982, 1986; Debouck et al., 2001).

The main route of DON metabolism includes conjugation with glucuronic acid to free DON and conjugation with glucuronic acid, for example, DON-Glucuronide (DON-GlcA), the most commonly used way to measure exposure. In addition to free DON and DON-GlcA, de-epoxy deoxynivalenol (DOM-1) is another metabolite present in body fluids associated with microbiota (Al-Jaal et al., 2019).

Free DON can be used as a biomarker to investigate the exposure of farm workers who handle grain or silage, showing satisfactory results in humans (Turner et al., 2010a). Among the conjugates with glucuronic acid, DON-15-Glycuronide is found in greater quantity in urine and is therefore a good biomarker of exposure to DON (Warth et al., 2012).

DON-1 is the metabolite found in lesser amounts in human urine samples (Turner et al., 2010b; Ali et al., 2016). DON-1 is found in greater proportion in animal samples and is a less toxic metabolite of DON derived from the metabolism of the intestinal microbiota. The low levels of DON-1 in humans may indicate a greater sensitivity to the toxic effects of DON (Turner et al., 2011).

\subsection{Ochratoxins}

Ochratoxins are secondary metabolic products of fungi of the genus Aspergillus spp. and Penicillium spp. found mainly in nuts, dried fruits, grapes and grapes-derived drinks (Rocha et al., 2014). It has a structure similar to that of phenylalanine, which makes this mycotoxin act to inhibit protein synthesis. Its effects include nephrotoxicity, hepatotoxicity, immunosuppression and teratogenesis (Al-Jaal et al., 2019). Within the group of Ochratoxins, the most important is Ochratoxin A (OTA), due to its ability to cause damage to human and animal health, being categorized by the International Agency for Research on Cancer (1993) as a potential carcinogen for humans, remaining in group $2 \mathrm{~B}$.

The most prominent damage caused by ingestion of OTA is due to nephrotoxicity, which can cause edema, necrosis and changes at the cellular level, such as karyomegaly and apoptosis, in several species. (Huff et al., 1975; Maaroufi et al., 1999). In humans, OTA has been identified at high levels in areas with a high incidence of endemic Balkan nephropathy and malignant neoplasms of the urinary tract (Simon, 1996; Castegnaro et al., 2006). The mechanism by which OTA causes nephrocarcinogenesis is still the subject of discussion. Considering the mechanism of adducts formation with DNA, hypotheses are raised that a series of epigenetic mechanisms are related to the carcinogenic potential of OTA. (Marin-Kuan et al., 2008; Pfohl-Leszkowicz \& Manderville, 2012).

As shown in experimental studies, OTA, which is metabolized in the liver via cytochrome P450, acts on hepatic metabolism, inducing changes in its metabolic pathways, thus leading to the development of liver diseases over time (Qi et al., 2014). The mechanisms by which OTA operates in the liver are mostly increased production of reactive oxygen species in hepatocytes, followed by lesions in DNA and stimulation of intrinsic apoptosis pathway activation (Gayathri et al., 2015).

OTA metabolites can be found in human and animal breast milk, which shows the risk of contamination during breastfeeding 


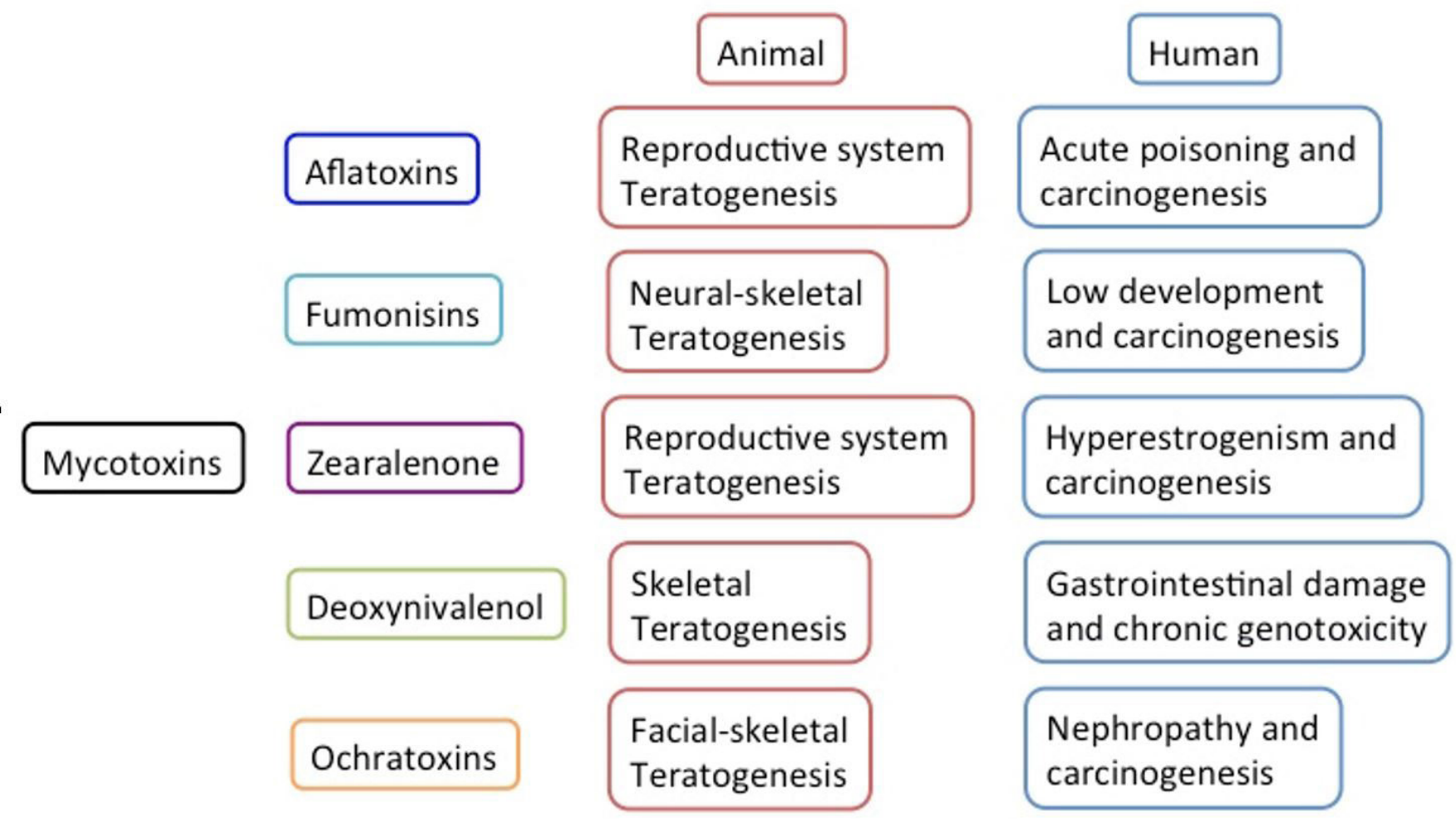

Figure 1. The main impact of aflatoxins, fumonisins, zearalenone, deoxynivalenol and ochratoxins on human and animal health.

and in dairy products (Breitholtz-Emanuelsson et al., 1993; Skaug, 1999; Skaug et al., 2001).

Experimental studies also suggest a great teratogenic potential of OTA. When evaluated for its effects in rats and mice, OTA has been related to increased prenatal mortality and decreased weight of puppies, bone, eye, and face malformations. When delivered in high doses, it leads to the death of fetuses (Hayes et al., 1974; Brown et al., 1976). A study conducted on perfused human placenta demonstrated ineffectiveness in transferring OTA, going against the results obtained in animals, and this is a point to be investigated in the future (Woo et al., 2012).

The most commonly used biomarkers for the diagnosis of exposure to OTA is OTA, ochratoxin $\alpha$ and $\beta$ (OT $\alpha$ and OT $\beta$ ), which are the products of hydrolysis by carboxypeptidases, and finally 4-R-hydroxyocratoxine (4-OH-OTA), which results from hydroxylation processes by enzymes of the cytochrome $\mathrm{P} 450$ family and peroxidases. All can be found in serum, plasma, and human and animal urine (Rocha et al., 2014; Al-Jaal et al., 2019). OTA can still be evidenced in milk, although the levels of biomarkers in urine indicate a better source to assess exposure (Scott, 2005).

A study conducted in adult Germans showed a greater amount of OTa in urine samples when compared to OTA, an inverse situation in the assessment of plasma levels of these biomarkers; the studies in this case indicate a greater amount of OTA in the blood when compared to OTa (Ali et al., 2017, 2018). Figure 1 summarizes the main damages of mycotoxins on human and animal health.
Finally, the improved detection of fungal biomarkers is also important for the investigation of alternatives that can minimize the presence of mycotoxins in foods, or at least neutralize their toxic and teratogenic effects. For example, the use of polymers with three-dimensional and specific sites (Bodbodak et al., 2018), as well as the biofilm of Lactobacillus rhamnosus (Assaf et al., 2019) for binding with AFM1, can reduce the presence of this mycotoxin in milk. The use of some lipid compounds has also been shown to be promising because in addition to having a mycostatic effect, they have antioxidant capacity, decreasing fungal toxicity (Bemvenuti et al., 2019; Villegas-Rascón et al., 2018).

\section{Conclusions}

Mycotoxin contamination of food is very relevant from a global health point of view, and understanding its mechanisms of action makes it increasingly possible to associate it with several diseases. To establish more precisely how these substances are associated with various pathologies, the measurement of exposure of populations based on their biomarkers is essential, which makes it important to know in detail the biotransformation of these substances and define the best markers to identify them. Another very important point is the chain reaction that can take place when the feed of farm animals is contaminated and then their products such as meat, milk and eggs become contaminants. Thus, due to its close correlation with human health, procedures for feeding farm animals should be optimized, with the rapid identification of pathogens, as well as the proposition of measures to reduce these damages. 


\section{References}

Abdel-Wahhab, M. A., Hassan, A. M., Amer, H. A., \& Naguib, K. M. (2004). Prevention of fumonisin-induced maternal and developmental toxicity in rats by certain plant extracts. Journal of Applied Toxicology, 24(6), 469-474. http://dx.doi.org/10.1002/jat.1000. PMid:15551383.

Ahmadi, E. (2020). Potential public health risk due to consumption of contaminated bovine milk with aflatoxin M1 and Coxiella burnetii in the West of Iran. International Journal of Dairy Technology, 73(3), 479-485. http://dx.doi.org/10.1111/1471-0307.12687.

Alamu, E. O., Gondwe, T., Akello, J., Maziya-Dixon, B., \& Mukanga, M. (2020). Relationship between serum aflatoxin concentrations and the nutritional status of children aged 6-24 months from Zambia. International Journal of Food Sciences and Nutrition, 71(5), 593-603. http://dx.doi.org/10.1080/09637486.2019.1689547. PMid:31718342.

Ali, N., \& Degen, G. H. (2018). Urinary biomarkers of exposure to the mycoestrogen zearalenone and its modified forms in German adults. Archives of Toxicology, 92(8), 2691-2700. http://dx.doi.org/10.1007/ s00204-018-2261-5. PMid:29980802.

Ali, N., Blaszkewicz, M., \& Degen, G. H. (2016). Assessment of deoxynivalenol exposure among Bangladeshi and German adults by a biomarker-based approach. Toxicology Letters, 258, 20-28. http:// dx.doi.org/10.1016/j.toxlet.2016.06.006. PMid:27298273.

Ali, N., Muñoz, K., \& Degen, G. H. (2017). Ochratoxin A and its metabolites in urines of German adults: an assessment of variables in biomarker analysis. Toxicology Letters, 275, 19-26. http://dx.doi. org/10.1016/j.toxlet.2017.04.013. PMid:28445738.

Ali, N., Hossain, K., \& Degen, G. H. (2018). Blood plasma biomarkers of citrinin and ochratoxin A exposure in young adults in Bangladesh. Mycotoxin Research, 34(1), 59-67. http://dx.doi.org/10.1007/s12550017-0299-5. PMid:29143924.

Al-Jaal, B. A., Jaganjac, M., Barcaru, A., Horvatovich, P., \& Latiff, A. (2019). Aflatoxin, fumonisin, ochratoxin, zearalenone and deoxynivalenol biomarkers in human biological fluids: a systematic literature review. Food and Chemical Toxicology, 129, 2011-228. http:// dx.doi.org/10.1016/j.fct.2019.04.047. PMid:31034935.

Assaf, J. C., Khoury, A. E., Chokr, A., Louka, N., \& Atoui, A. (2019). A novel method for elimination of aflatoxin M1 in milk using Lactobacillus rhamnosus GG biofilm. International Journal of Dairy Technology, 72(2), 248-256. http://dx.doi.org/10.1111/1471-0307.12578.

Azziz-Baumgartner, E., Lindblade, K., Gieseker, K., Rogers, H. S., Kieszak, S., Njapau, H., Schleicher, R., McCoy, L. F., Misore, A., DeCock, K., Rubin, C., \& Slutsker, L. (2005). Case-control study of an acute aflatoxicosis outbreak, Kenya. (2004). Environmental Health Perspectives, 113(12), 1779-1783. http://dx.doi.org/10.1289/ ehp.8384. PMid:16330363.

Bando, É., Gonçales, L. N., Tamura, N. K., \& Machinski, M. Jr. (2007). Biomarcadores para avaliação da exposição humana às micotoxinas. Jornal Brasileiro de Patologia e Medicina Laboratorial, 43(3), 175-180. http://dx.doi.org/10.1590/S1676-24442007000300006.

Batatinha, M. J., Simas, M. M. S., \& Górniak, S. L. (2008). Micotoxicoses. In H. S. Spinosa, S. L. Górniak \& J. Palermo-Neto (Eds.), Toxicologia aplicada à medicina veterinária. São Paulo: Manole.

Belhassen, H., Jiménez-Díaz, I., Arrebola, J. P., Ghali, R., Ghorbel, H., Olea, N., \& Hedili, A. (2015). Zearalenone and its metabolites in urine and breast cancer risk: a case-control study in Tunisia. Chemosphere, 128, 1-6. http://dx.doi.org/10.1016/j.chemosphere.2014.12.055. PMid:25602441.

Bemvenuti, R., Rodrigues, M. H., \& Furlong, E. (2019). Efficiency of $\gamma$-oryzanol against the complex Fusarium graminearum growth and mycotoxins production. Food Science and Technology, 39(1), 240-246. http://dx.doi.org/10.1590/fst.01818.

Bennett, J. W., \& Klich, M. (2003). Mycotoxins. Clinical Microbiology Reviews, 16(3), 497-516. http://dx.doi.org/10.1128/CMR.16.3.497516.2003. PMid:12857779.

Bodbodak, S., Hesari, J., Peighambardoust, S. H., \& Mahkam, M. (2018). Selective decontamination of aflatoxin M1 in milk by molecularly imprinted polymer coated on the surface of stainless steel plate. International Journal of Dairy Technology, 71(4), 868-878. http:// dx.doi.org/10.1111/1471-0307.12551.

Breitholtz-Emanuelsson, A., Olsen, M., Oskarsson, A., Palminger, I., \& Hult, K. (1993). Ochratoxin A in cow's milk and in human milk with corresponding human blood samples. Journal of AOAC International, 76(4), 842-846. http://dx.doi.org/10.1093/jaoac/76.4.842. PMid:8374329.

Brown, M. H., Szczech, G. M., \& Purmalis, B. P. (1976). Teratogenic and toxic effects of ochratoxin A in rats. Toxicology and Applied Pharmacology, 37(2), 331-338. http://dx.doi.org/10.1016/0041008X(76)90096-X. PMid:982455.

Bryden, W. L. (2007). Mycotoxins in the food chain: human health implications. Asia Pacific Journal of Clinical Nutrition, 16(1, Suppl. 1), 95-101. PMid:17392084.

Cai, Q., Tang, L., \& Wang, J.-S. (2007). Validation of fumonisin biomarkers in F344 rats. Toxicology and Applied Pharmacology, 225(1), 28-39. http://dx.doi.org/10.1016/j.taap.2007.06.027. PMid:17904604.

Caldas, E. D., Silva, S. C., \& Oliveira, J. N. (2002). Aflatoxinas e Ochratoxina A em alimentos e riscos para a saúde humana. Revista de Saúde Pública, 36(3), 319-323. http://dx.doi.org/10.1590/S003489102002000300010. PMid:12131971.

Calori-Domingues, M. A., Bernardi, C. M., Nardin, M. S., Souza, G. V., Santos, F. G., Stein, M., Gloria, E. M., Dias, C. T., \& Camargo, A. C. (2016). Co-occurrence and distribution of deoxynivalenol, nivalenol and zearalenone in wheat from Brazil. Food Additives and Contaminants, 9(2), 142-151. http://dx.doi.org/10.1080/19393210. 2016.1152598. PMid:26886061.

Castegnaro, M., Canadas, D., Vrabcheva, T., Petkova-Bocharova, T., Chernozemsky, I. N., \& Pfohl-Leszkowicz, A. (2006). Balkan endemic nephropathy: Role of ochratoxins A through biomarkers. Molecular Nutrition \& Food Research, 50(6), 519-529. http://dx.doi. org/10.1002/mnfr.200500182. PMid:16715544.

Chauhan, R., Singh, J., Sachdev, T., Basu, T., \& Malhotra, B. D. (2016). Recent advances in mycotoxins detection. Biosensors \& Bioelectronics, 81, 532-545. http://dx.doi.org/10.1016/j.bios.2016.03.004. PMid:27019032.

Chawanthayatham, S., Thiantanawat, A., Egner, P. A., Groopman, J. D., Wogan, G. N., Croy, R. G., \& Essigmann, J. M. (2015). Prenatal exposure of mice to the human liver carcinogen aflatoxin B1 reveals a critical window of susceptibility to genetic change. International Journal of Cancer, 136(6), 1254-1262. http://dx.doi.org/10.1002/ ijc.29102. PMid:25070670.

Chen, C., Riley, R. T., \& Wu, F. (2018). Dietary fumonisin and growth impairment in children and animals: a review. Food Science and Food Safety, 17(6), 1448-1464. http://dx.doi.org/10.1111/1541-4337.12392.

Chiaradia, M. C., Collins, C. H., \& Jardim, I. C. S. F. (2008). O estado da arte da cromatografia associada à espectrometria de massas acoplada à espectrometria de massas na análise de compostos tóxicos em alimentos. Quimica Nova, 31(3), 623-636. http://dx.doi. org/10.1590/S0100-40422008000300030.

Come, J., Cambaza, E., Ferreira, R., da Costa, J., Carrilho, C., \& Santos, L. L. (2019). Esophageal cancer in Mozambique: should mycotoxins 
be a concern? The Pan African Medical Journal, 33, 187. http://dx.doi. org/10.11604/pamj.2019.33.187.18295. PMid:31565147.

Debouck, C., Haubruge, E., Bollaerts, P., Van Bignoot, D., Brostaux, Y., Werry, A., \& Rooze, M. (2001). Skeletal deformities induced by the intraperitoneal administration of deoxynivalenol (vomitoxin) in mice. International Orthopaedics, 25(3), 194-198. http://dx.doi. org/10.1007/s002640100235. PMid:11482540.

Dias, A. S. (2018). Micotoxinas em produtos de origem animal. Revista Científica Eletrônica de Medicina Veterinária, 5, 1-15.

Diaz, G. J., \& Sánchez, M. P. (2015). Determination of aflatoxin M1 in breast milk as a biomarker of maternal and infant exposure in Colombia. Food Additives and Contaminants, 32(7), 1192-1198. http://dx.doi.org/10.1080/19440049.2015.1049563. PMid:25959253.

Dohnal, V., Wu, Q., \& Kuca, K. (2014). Metabolism of aflatoxins: key enzymes and interindividual as well as interspecies differences. Archives of Toxicology, 88(9), 1635-1644. http://dx.doi.org/10.1007/ s00204-014-1312-9. PMid:25027283.

Fernandez, A., Belío, R., Ramos, J. J., Sanz, M. C., \& Saez, T. (1997). Aflatoxins and their metabolites in the tissues, faeces and urine from lambs feeding on an aflatoxin-contaminated diet. Journal of the Science of Food and Agriculture, 74(2), 161-168. http://dx.doi.org/10.1002/ (SICI)1097-0010(199706)74:2<161::AID-JSFA783>3.0.CO;2-D.

Fetaih, H. A., Dessouki, A. A., Hassanin, A. A., \& Tahan, A. S. (2014). Toxopathological and cytogenetic effects of aflatoxin B1 (AFB1) on pregnant rats. Pathology, Research and Practice, 210(12), 10791089. http://dx.doi.org/10.1016/j.prp.2014.06.001. PMid:25023881.

Fioramonti, J., Dupuy, C., Dupuy, J., \& Bueno, L. (1993). The mycotoxin, deoxynivalenol, delays gastric emptying through serotonin-3 receptors in rodents. The Journal of Pharmacology and Experimental Therapeutics, 266(3), 1255-1260. PMid:8371135.

Fitzpatrick, D. W., Picken, C. A., Murphy, L. C., \& Buhr, M. M. (1989). Measurement of the relative binding affinity of zearalenone, alphazearalenol and beta-zearalenol for uterine and oviduct estrogen receptors in swine, rats and chickens: an indicator of estrogenic potencies. Comparative Pharmacology and Toxicology, 94(2), 691-694. http://dx.doi.org/10.1016/0742-8413(89)90133-3. PMid:2576797.

Frizzell, C., Uhlig, S., Miles, C. O., Verhaegen, S., Elliott, C. T., Eriksen, G. S., Sørlie, M., Ropstad, E., \& Connolly, L. (2015). Biotransformation of zearalenone and zearalenols to their major glucuronide metabolites reduces estrogenic activity. Toxicology In Vitro, 29(3), 575-581. http:// dx.doi.org/10.1016/j.tiv.2015.01.006. PMid:25645597.

Gayathri, L., Dhivya, R., Dhanasekaran, D., Periasamy, V. S., Alshatwi, A. A., \& Akbarsha, M. A. (2015). Hepatotoxic effect of ochratoxin A and citrinin, alone and in combination and protective effect of vitamin E: in vitro study in HepG2 cell. Food and Chemical Toxicology, 83, 151-163. http://dx.doi.org/10.1016/j.fct.2015.06.009. PMid:26111808.

Gelineau-van Waes, J., Voss, K. A., Stevens, V. L., Speer, M. C., \& Riley, R. T. (2009). Maternal fumonisin exposure as a risk factor for neural tube defects. Advances in Food and Nutrition Research, 56, 145-181. http://dx.doi.org/10.1016/S1043-4526(08)00605-0. PMid:19389609.

Giovati, L., Magliani, W., Ciociola, T., Santinoli, C., Conti, S., \& Polonelli, L. (2015). AFM1 in milk: physical, biological, and prophylactic methods to mitigate contamination. Toxins, 7(10), 4330-4349. http:// dx.doi.org/10.3390/toxins7104330. PMid:26512694.

Gong, Y. Y., Cardwell, K., Hounsa, A., Egal, S., Turner, P. C., Hall, A. J., \& Wild, C. P. (2002). Dietary aflatoxin exposure and impaired growth in young children from Benin and Togo: cross sectional study. BMJ, 325(7354), 20-21. http://dx.doi.org/10.1136/bmj.325.7354.20. PMid:12098724.
Groopman, J. D., \& Kensler, T. W. (1999). The light at the end of the tunnel for chemical-specific biomarkers: daylight or headlight? Carcinogenesis, 20(1), 1-11. http://dx.doi.org/10.1093/carcin/20.1.1. PMid:9934843.

Hajmohammadi, M., Valizadeh, R., Naserian, A., Nourozi, M. E., Rocha, R. S., \& Oliveira, C. A. F. (2019). Composition and occurrence of aflatoxin M1 in cow's milk samples from Razavi Khorasan Province, Iran. International Journal of Dairy Technology, 73(1), 40-45. http:// dx.doi.org/10.1111/1471-0307.12661.

Harrison, L. R., Colvin, B. M., Greene, J. T., Newman, L. E., \& Cole, J. R. Jr. (1990). Pulmonary edema and hydrothorax in swine produced by fumonisin B1, a toxic metabolite of Fusarium moniliforme. Journal of Veterinary Diagnostic Investigation, 2(3), 217-221. http://dx.doi. org/10.1177/104063879000200312. PMid:2094448.

Hayes, A. W., Hood, R. D., \& Lee, H. L. (1974). Teratogenic effects of ochratoxin A in mice. Teratology, 9(1), 93-97. http://dx.doi. org/10.1002/tera.1420090112. PMid:4204660.

Hilakivi-Clarke, L., Onojafe, I., Raygada, M., Cho, E., Skaar, T., Russo, I., \& Clarke, R. (1999). Prepubertal exposure to zearalenone or genistein reduces mammary tumorigenesis. British Journal of Cancer, 80(11), 1682-1688. http://dx.doi.org/10.1038/sj.bjc.6690584. PMid:10468283.

Huff, W. E., Wyatt, R. D., \& Hamilton, P. B. (1975). Nephrotoxicity of dietary ochratoxin A in broiler chikens. Applied Microbiology, 30(1), 48-51. http://dx.doi.org/10.1128/AM.30.1.48-51.1975. PMid:1147620.

International Agency for Research on Cancer - IARC. (1993). Some naturally occurring substances: food items and constituents, heterocyclic aromatic amines and mycotoxins (IARC Monographs on the Evaluation of Carcinogenic Risks to Humans, No. 56). Lyon: IARC.

International Agency for Research on Cancer - IARC. (2002). Some traditional herbal medicines, some mycotoxins, naphthalene and styrene (IARC Monographs on the Evaluation of Carcinogenic Risks to Humans, No. 82). Lyon: IARC. PMid:12687954.

Jager, A. V., Tonin, F. G., Baptista, G. Z., Souto, P. C., \& Oliveira, C. A. (2016). Assessment of aflatoxin exposure using serum and urinary biomarkers in São Paulo, Brazil: a pilot study. International Journal of Hygiene and Environmental Health, 219(3), 294-300. http://dx.doi. org/10.1016/j.ijheh.2015.12.003. PMid:26740158.

Khera, K. S., Whalen, C., \& Angers, G. (1986). A teratology study on vomitoxin (4-deoxynivalenol) in rabbits. Food and Chemical Toxicology, 24(5), 421-424. http://dx.doi.org/10.1016/0278-6915(86)90207-3. PMid:3744196.

Khera, K., Whalen, C., Angers, G., Vesonder, R., \& Kuiper-Goodman, T. (1982). Embryotoxicity of 4-deoxynivalenol (vomitoxin) in mice. Bulletin of Environmental Contamination and Toxicology, 29(4), 487-491. http://dx.doi.org/10.1007/BF01605616. PMid:7171859.

Kowalska, K., Habrowska-Górczyńska, D. E., \& Piastowska-Ciesielska, A. W. (2016). Zearalenone as an endocrine disruptor in humans. Environmental Toxicology and Pharmacology, 48, 141-149. http:// dx.doi.org/10.1016/j.etap.2016.10.015. PMid:27771507.

Liu, X., Fan, L., Yin, S., Chen, H., \& Hu, H. (2019). Molecular mechanisms of fumonisin B1-induced toxicities and its applications in the mechanism-based interventions. Toxicon, 167, 175. http://dx.doi. org/10.1016/j.toxicon.2019.06.009. PMid:31173793.

Maaroufi, K., Zakhama, A., Baudrimont, I., Achour, A., Abid, S., Ellouz, F., Dhouib, S., Creppy, E. E., \& Bacha, H. (1999). Karyomegaly of tubular cells as early stage marker of the nephrotoxicity induced by ochratoxin A in rats. Human and Experimental Toxicology, 18(6), 410-415. http://dx.doi.org/10.1191/096032799678840192. PMid:10413246. 
Maragos, C. (2010). Zearalenone occurrence and human exposure. World Mycotoxin Journal, 3(4), 369-383. http://dx.doi.org/10.3920/ WMJ2010.1240.

Marasas, W. F., Kellerman, T. S., Gelderblom, W. C., Coetzer, J. A., Thiel, P. G., \& Van der Lugt, J. J. (1988). Leukoencephalomalacia in a horse induced by fumonisin B1 isolated from Fusarium moniliforme. The Onderstepoort Journal of Veterinary Research, 55(4), 197-203. PMid:3217091.

Maresca, M., Mahfoud, R., Garmy, N., \& Fantini, J. (2002). The mycotoxin deoxynivalenol affects nutrient absorption in human intestinal epithelial cells. The Journal of Nutrition, 132(9), 2723-2731. http:// dx.doi.org/10.1093/jn/132.9.2723. PMid:12221236.

Marin, S., Ramos, A. J., Cano-Sancho, G., \& Sanchis, V. (2013). Mycotoxins: occurrence, toxicology, and exposure assessment. Food and Chemical Toxicology, 60, 218-237. http://dx.doi.org/10.1016/j. fct.2013.07.047. PMid:23907020.

Marin-Kuan, M., Cavin, C., Delatour, T., \& Schilter, B. (2008). Ochratoxin A carcinogenicity involves a complex network of epigenetic mechanisms. Toxicon, 52(2), 195-202. http://dx.doi.org/10.1016/j. toxicon.2008.04.166. PMid:18649906.

Maziero, M. T., \& Bersot, L. S. (2010). Micotoxinas em alimentos produzidos no Brasil. Revista Brasileira de Produtos Agroindustriais, 12(1), 89-99. http://dx.doi.org/10.15871/1517-8595/rbpa.v12n1p89-99.

McMillan, A., Renaud, J. B., Burgess, K., Orimadegun, A. E., Akinyinka, O. O., Allen, S. J., Miller, J. D., Reid, G., \& Sumarah, M. W. (2018). Aflatoxin exposure in Nigerian children with severe acute malnutrition. Food and Chemical Toxicology, 111, 356-362. http:// dx.doi.org/10.1016/j.fct.2017.11.030. PMid:29175577.

Medina, B. G., Sartori, A. V., Moraes, M. H. P., Cardoso, M. H. W. M., \& Jacob, S. C. (2019). Validation and application of an analytical method for the determination of mycotoxins in crackers by UPLCMS/MS. Food Science and Technology, 39(3), 583-591. http://dx.doi. org/10.1590/fst.33717.

Mitchell, N. J., Kumi, J., Johnson, N. M., Dotse, E., Marroquin-Cardona, A., Wang, J. S., Jolly, P. E., Ankrah, N. A., \& Phillips, T. D. (2013). Reduction in the urinary aflatoxin M1 biomarker as an early indicator of the efficacy of dietary interventions to reduce exposure to aflatoxins. Biomarkers, 18(5), 391-398. http://dx.doi.org/10.310 9/1354750X.2013.798031. PMid:23697800.

Mupunga, I., Izaaks, C. D., Shai, L. J., \& Katerere, D. R. (2017). Aflatoxin biomarkers in hair may facilitate long-term exposure studies. Journal of Applied Toxicology, 37(4), 395-399. http://dx.doi.org/10.1002/ jat.3422. PMid:27933645.

Mykkänen, H., Zhu, H., Salminen, E., Juvonen, R. O., Ling, W., Ma, J., Polychronaki, N., Kemiläinen, H., Mykkänen, O., Salminen, S., \& El-Nezami, H. (2005). Fecal and urinary excretion of aflatoxin B1 metabolites (AFQ1, AFM1 and AFB-N7-guanine) in young Chinese males. International Journal of Cancer, 115(6), 879-884. http://dx.doi.org/10.1002/ijc.20951. PMid:15723309.

Pan, P., Ma, F., Wu, K., Yu, Y., Li, Y., Li, Z., Chen, X., Huang, T., Wang, Y., \& Ge, R. S. (2020). Maternal exposure to zearalenone in masculinization window affects the fetal Leydig cell development in rat male fetus. Environmental Pollution, 263(Pt B), 114357. http:// dx.doi.org/10.1016/j.envpol.2020.114357. PMid:32229375.

Payros, D., Dobrindt, U., Martin, P., Secher, T., Bracarense, A. P., Boury, M., Laffitte, J., Pinton, P., Oswald, E., \& Oswald, I. P. (2017). The food contaminant deoxynivalenol exacerbates the genotoxicity of gut microbiota. mBio, 8(2), e00007-17. http://dx.doi.org/10.1128/ mBio.00007-17. PMid:28292979.
Peraica, M., Radić, B., Lucić, A., \& Pavlović, M. (1999). Toxic effects of mycotoxins in humans. Bulletin of the World Health Organization, 77(9), 754-766. PMid:10534900.

Pestka, J. J., \& Smolinski, A. T. (2005). Deoxynivalenol: toxicology and potential effects on humans. Journal of Toxicology and Environmental Health, 8(1), 39-69. http://dx.doi.org/10.1080/10937400590889458. PMid:15762554.

Pestka, J. J. (2007). Deoxynivalenol: Toxicity, mechanisms and animal health risks. Animal Feed Science and Technology, 137(3-4), 283-298. http://dx.doi.org/10.1016/j.anifeedsci.2007.06.006.

Pestka, J. J. (2010). Deoxynivalenol: mechanisms of action, human exposure, and toxicological relevance. Archives of Toxicology, 84(9), 663-679. http://dx.doi.org/10.1007/s00204-010-0579-8. PMid:20798930.

Pfohl-Leszkowicz, A., \& Manderville, R. A. (2012). An update on direct genotoxicity as a molecular mechanism of ochratoxin A carcinogenicity. Chemical Research in Toxicology, 25(2), 252-262. http://dx.doi.org/10.1021/tx200430f. PMid:22054007.

Pimpitak, U., Rengpipat, S., Phutong, S., Buakeaw, A., \& Komolpis, K. (2020). Development and validation of a lateral flow immunoassay for the detection of aflatoxin M1 in raw and commercialised milks. International Journal of Dairy Technology, 73(4), 695-705. http:// dx.doi.org/10.1111/1471-0307.12728.

Qi, X., Yang, X., Chen, S., He, X., Dweep, H., Guo, M., \& Huang, K. (2014). Ochratoxin A induced early hepatotoxicity: new mechanistic insights from microRNA, mRNA and proteomic profiling studies. Scientific Reports, 4(1). http://dx.doi.org/10.1038/srep05163.

Qiu, M., \& Liu, X. (2001). Determination of sphinganine, sphingosine and $\mathrm{Sa} / \mathrm{So}$ ratio in urine of humans exposed to dietary fumonisin B1. Food Additives and Contaminants, 18(3), 263-269. http://dx.doi. org/10.1080/02652030117470. PMid:11304035.

Ramalho, L., Porta, L. D., Rosim, R. E., Petta, T., Augusto, M. J., Silva, D. M., Ramalho, F. S., \& Oliveira, C. (2018). Aflatoxin B1 residues in human livers and their relationship with markers of hepatic carcinogenesis in São Paulo, Brazil. Toxicology Reports, 5, 777-784. http://dx.doi.org/10.1016/j.toxrep.2018.07.005. PMid:30101081.

Raota, C. S., \& Giovanela, M. (2016). Análise quantitativa de aflatoxinas B1, B2, G1 e G2 em ração para aves de corte por cromatografia líquida de alta eficiência com detecção por fluorescência. Scientia cum Industria, 4(3), 148-153. http://dx.doi.org/10.18226/23185279. v4iss3p148.

Rocha, E. B., Freire, F. C. O., Maia, E. F., Guedes, I. F., \& Rondina, D. (2014). Mycotoxins and their effects on human and animal health. Food Control, 36(1), 159-165. http://dx.doi.org/10.1016/j. foodcont.2013.08.021.

Rogers, A., \& Newberne, P. (1971). Nutrition and aflatoxin carcinogenesis. Nature, 229(5279), 62-63. http://dx.doi.org/10.1038/229062a0. PMid:4098983.

Rudyk, H., Tomaszewska, E., Kotsyumbas, I., Muszyński, S., TomczykWarunek, A., Szymańczyk, S., Dobrowolski, P., Wiącek, D., Kamiński, D., \& Brezvyn, O. (2019). Bone homeostasis in experimental fumonisins intoxication of rats. Annals of Animal Science, 19(2), 403-419. http://dx.doi.org/10.2478/aoas-2019-0003.

Scott, P. M. (2005). Biomarkers of human exposure to ochratoxin A. Food Additives and Contaminants, 22(1, Suppl 1), 99-107. http:// dx.doi.org/10.1080/02652030500410315. PMid:16332628.

Sewram, V., Mshicileli, N., Shephard, G. S., \& Marasas, W. F. (2003). Fumonisin mycotoxins in human hair. Biomarkers, 8(2), 110-118. http://dx.doi.org/10.1080/1354750031000081002. PMid:12775496. 
Simon, P. (1996). Ochratoxin and kidney disease in the human. Journal of Toxicology. Toxin Reviews, 15(3), 239-249. http://dx.doi. org/10.3109/15569549609016446.

Skaug, M. A. (1999). Analysis of Norwegian milk and infant formulas for ochratoxin A. Food Additives and Contaminants, 16(2), 75-78. http://dx.doi.org/10.1080/026520399284235. PMid:10435076.

Skaug, M. A., Helland, I., Solvoll, K., \& Saugstad, O. D. (2001). Presence of ochratoxin A in human milk in relation to dietary intake. Food Additives and Contaminants, 18(4), 321-327. http://dx.doi. org/10.1080/02652030117740. PMid:11339267.

Smith, J. E., Solomons, G., Lewis, C., \& Anderson, J. G. (1995). Role of mycotoxins in human and animal nutrition and health. Natural Toxins, 3(4), 187-221. http://dx.doi.org/10.1002/nt.2620030404. PMid:7582615.

Sobrova, P., Adam, V., Vasatkova, A., Beklova, M., Zeman, L., \& Kizek, R. (2010). Deoxynivalenol and its toxicity. Interdisciplinary Toxicology, 3(3), 94-99. http://dx.doi.org/10.2478/v10102-0100019-x. PMid:21217881.

Souto, P., Jager, A. V., Tonin, F. G., Petta, T., Di Gregório, M. C., Cossalter, A. M., Pinton, P., Oswald, I. P., Rottinghaus, G. E., \& Oliveira, C. (2017). Determination of fumonisin B1 levels in body fluids and hair from piglets fed fumonisin B1-contaminated diets. Food and Chemical Toxicology, 108(Pt A), 1-9. http://dx.doi.org/10.1016/j. fct.2017.07.036. PMid:28733235.

Supriya, C. H., \& Reddy, P. S. (2015). Prenatal exposure to aflatoxin B1: developmental, behavioral, and reproductive alterations in male rats. Naturwissenschaften, 102(5-6), 26. http://dx.doi.org/10.1007/ s00114-015-1274-7. PMid:25911313.

Sweeney, M. J., \& Dobson, A. D. (1998). Mycotoxin production by Aspergillus, Fusarium and Penicillium species. International Journal of Food Microbiology, 43(3), 141-158. http://dx.doi.org/10.1016/ S0168-1605(98)00112-3. PMid:9801191.

Turner, N. W., Subrahmanyam, S., \& Piletsky, S. A. (2009). Analytical methods for determination of mycotoxins: a review. Analytica Chimica Acta, 632(2), 168-180. http://dx.doi.org/10.1016/j.aca.2008.11.010. PMid:19110091.

Turner, P. C., Hopton, R. P., Lecluse, Y., White, K. L. M., Fisher, J., \& Lebailly, P. (2010a). Determinants of urinary deoxynivalenol and de-epoxy deoxynivalenol in male farmers from Normandy, France. Journal of Agricultural and Food Chemistry, 58(8), 5206-5212. http:// dx.doi.org/10.1021/jf100892v. PMid:20349912.

Turner, P. C., White, K. L., Burley, V. J., Hopton, R. P., Rajendram, A., Fisher, J., Cade, J. E., \& Wild, C. P. (2010b). A comparison of deoxynivalenol intake and urinary deoxynivalenol in UK adults. Biomarkers, 15(6), 553-562. http://dx.doi.org/10.3109/135475 0X.2010.495787. PMid:20572795.

Turner, P. C., Ji, B. T., Shu, X. O., Zheng, W., Chow, W. H., Gao, Y. T., \& Hardie, L. J. (2011). A biomarker survey of urinary deoxynivalenol in China: the Shanghai Women's Health Study. Food Additives and Contaminants, 28(9), 1220-1223. http://dx.doi.org/10.1080/19440 049.2011.584070. PMid:21774617.

Van de Walle, J. V., Sergent, T., Piront, N., Toussaint, O., Schneider, Y. J., \& Larondelle, Y. (2010). Deoxynivalenol affects in vitro intestinal epithelial cell barrier integrity through inhibition of protein synthesis. Toxicology and Applied Pharmacology, 245(3), 291-298. http://dx.doi. org/10.1016/j.taap.2010.03.012. PMid:20362602.
Van der Westhuizen, L., Brown, N. L., Marasas, W. F., Swanevelder, S., \& Shephard, G. S. (1999). Sphinganine/sphingosine ratio in plasma and urine as a possible biomarker for fumonisin exposure in humans in rural areas of Africa. Food and Chemical Toxicology, 37(12), 1153-1158. http://dx.doi.org/10.1016/S0278-6915(99)001131. PMid:10654591.

Villegas-Rascón, R. E., López-Meneses, A. K., Plascencia-Jatomea, M., Cota-Arriola, O., Moreno-Ibarra, G. M., Castillón-Campaña, L. G., Sánchez-Mariñez, R. I., \& Cortez-Rocha, M. O. (2018). Control of mycotoxigenic fungi with microcapsules of essential oils encapsulated in chitosan. Food Science and Technology, 38(2), 335-340. http:// dx.doi.org/10.1590/1678-457x.04817.

Voss, K. A., \& Riley, R. T. (2013). Fumonisin toxicity and mechanism of action: overview and current perspectives. Food Safety, 1(1), 2013006. http://dx.doi.org/10.14252/foodsafetyfscj.2013006.

Warth, B., Preindl, K., Manser, P., Wick, P., Marko, D., \& BuerkiThurnherr, T. (2019). Transfer and metabolism of the xenoestrogen zearalenone in human perfused placenta. Environmental Health Perspectives, 127(10), 107004. http://dx.doi.org/10.1289/EHP4860. PMid:31596610.

Warth, B., Sulyok, M., Fruhmann, P., Berthiller, F., Schuhmacher, R., Hametner, C., Adam, G., Fröhlich, J., \& Krska, R. (2012). Assessment of human deoxynivalenol exposure using an LC-MS/MS based biomarker method. Toxicology Letters, 211(1), 85-90. http://dx.doi. org/10.1016/j.toxlet.2012.02.023. PMid:22429874.

Wild, C. P., \& Turner, P. C. (2002). The toxicology of aflatoxins as a basis for public health decisions. Mutagenesis, 17(6), 471-481. http:// dx.doi.org/10.1093/mutage/17.6.471 PMid:12435844.

Woo, C. S. J., Partanen, H., Myllynen, P., Vähäkangas, K., \& El-Nezami, H. (2012). Fate of the teratogenic and carcinogenic ochratoxin A in human perfused placenta. Toxicology Letters, 208(1), 92-99. http:// dx.doi.org/10.1016/j.toxlet.2011.10.013. PMid:22037670.

Xu, L., Cai, Q., Tang, L., Wang, S., Hu, X., Su, J., Sun, G., \& Wang, J. S. (2010). Evaluation of fumonisin biomarkers in a cross-sectional study with two high-risk populations in China. Food Additives \& Contaminants. Part A, Chemistry, Analysis, Control, Exposure \& Risk Assessment, 27(8), 1161-1169. http://dx.doi.org/10.1080/194 40049.2010.481638. PMid:20589550.

Yang, D., Jiang, T., Lin, P., Chen, H., Wang, L., Wang, N., Zhao, F., Tang, K., Zhou, D., Wang, A., \& Jin, Y. (2017). Apoptosis inducing factor gene depletion inhibits zearalenone-induced cell death in a goat Leydig cell line. Reproductive Toxicology, 67, 129-139. http://dx.doi. org/10.1016/j.reprotox.2016.12.005. PMid:28011299.

Yang, W., Yu, M., Fu, J., Bao, W., Wang, D., Hao, L., Yao, P., Nüssler, A. K., Yan, H., \& Liu, L. (2014). Deoxynivalenol induced oxidative stress and genotoxicity in human peripheral blood lymphocytes. Food and Chemical Toxicology, 64, 383-396. http://dx.doi.org/10.1016/j. fct.2013.12.012. PMid:24355168.

Yu, Z., Zhang, L., Wu, D., \& Liu, F. (2005). Anti-apoptotic action of zearalenone in MCF-7 cells. Ecotoxicology and Environmental Safety, 62(3), 441-446. http://dx.doi.org/10.1016/j.ecoenv.2004.10.003. PMid:16216639.

Zheng, W. L., Wang, B. J., Wang, L., Shan, Y. P., Zou, H., Song, R. L., Wang, T., Gu, J. H., Yuan, Y., Liu, X. Z., Zhu, G. Q., Bai, J. F., Liu, Z. P., \& Bian, J. C. (2018). ROS-mediated cell cycle arrest and apoptosis induced by zearalenone in mouse Sertoli cells via ER stress and the ATP/AMPK pathway. Toxins, 10(1), 24. http://dx.doi.org/10.3390/ toxins10010024. PMid:29301253. 